Article

\title{
The Selective Politicization of Transatlantic Trade Negotiations
}

\author{
Aukje van Loon \\ Chair of International Politics, Faculty of Social Science, Ruhr University Bochum, 44801 Bochum, Germany; \\ E-Mail: aukje.vanloon@rub.de
}

Submitted: 31 October 2019 | Accepted: 29 January 2020 | Published: 31 March 2020

\begin{abstract}
European Union (EU) trade policy is in the spotlight. The Transatlantic Trade and Investment Partnership (TTIP) negotiations triggered substantial public mobilization which emerged in a surge of literature on trade politicization. Notwithstanding politicization's topicality and significance, it varies considerably over time, across trade agreements negotiations as well as across EU member states. By picking up on the latter, this article examines why, despite similar economic benefits potentially to be gained from trade liberalization, TTIP negotiations revealed striking differences in politicization in Germany and the UK. Understanding this variation is illustrated by highlighting the impact of some of TTIPs' substantial issues mobilizing a range of materially and ideationally motivated stakeholders, who in turn shaped diverging governments' trade positions of the countries under scrutiny. In explaining this selective politicization across two European countries, focus is on three explanatory variables, domestic material interests (business associations and trade unions), societal ideas (voters and non-governmental organizations [NGOs]) dominant in these countries' domestic politics, as well as their interaction with national institutions. For this reason, the societal approach to governmental preference formation is employed which provides a detailed exploration of these three domestic factors, as well as the importance of their interdependence, in shaping the TTIP positions of the UK and German governments.
\end{abstract}

\section{Keywords}

domestic politics; European Union; Germany; investment; politicization; trade policy; Transatlantic Trade and Investment Partnership; United Kingdom

\section{Issue}

This article is part of the issue "Politicization of EU Trade Policy across Time and Space" edited by Dirk De Bièvre (University of Antwerp, Belgium), Oriol Costa (Universitat Autònoma de Barcelona, Spain/IBEI, Spain), Leif Johan Eliasson (East Stroudsburg University, USA) and Patricia Garcia-Duran (University of Barcelona, Spain).

(C) 2020 by the author; licensee Cogitatio (Lisbon, Portugal). This article is licensed under a Creative Commons Attribution 4.0 International License (CC BY).

\section{Introduction}

Throughout the last decade European Union (EU) trade policy, the oldest and most integrated policy, was viewed as a rather depoliticized and overlooked field of studies; research and literature were slim (Dür \& Zimmermann, 2007, p. 772). Recently a remarkable surge in research has developed, due to alluring developments such as the stronger involvement of the European Parliament in trade policy decision making, the expansion of the trade agenda including content previously detached from free trade-triggering a more active engagement of nontraditional societal actors-and negotiations with new, essentially peer-like trade actors such as the United States (US) and China (van Loon, 2018a). Particularly due to the increase of public interest in and salience of trade agreements negotiations, EU trade policy is in the spotlight, suggesting that it, in contrast to the past, has become a profoundly politicized policy area. Research has picked up on the prominence of trade politicization, specifically revealed by the recent special issues of the Journal of European Integration (2017), the Journal of European Public Policy (2019) and this current Politics and Governance thematic issue. Equally, the European Commission's response to the increased public opposition to trade negotiations highlights a change from 'business as usual'; the time when EU trade policy was still perceived as a technocratic activity and both the public and the media were indifferent. In its Balanced and Progressive Trade Policy, the Commission felt prompted 
to react to a continually changing environment and increased public salience; 'How we conduct trade policy and trade negotiations matters. If the $\mathrm{EU}$ is to deliver effective agreements that benefit all citizens, the crafting of these agreements must be accountable, transparent, and inclusive' (European Commission, 2017, p. 8).

Withstanding the trade politicization hype however, this study acknowledges that, although claims about politicization are contemporary as well as significant, it varies considerably over time, across trade agreements negotiations as well as across EU member states. EU trade policy's depiction as a highly contested issue area with politicization spilling over to other trade agreements, or to the idea of free trade in general, is thus overly exaggerated (Young, 2019, p. 14). During the time period from 2005 until 2016, despite the Eurozone debt crisis and the Comprehensive Economic and Trade Agreement (CETA) as well as the Transatlantic Trade and Investment Partnership (TTIP) negotiations, there was no widespread hostility towards trade liberalization with considerable majorities in all EU member states having had continuous positive views of free trade, ranging between $68 \%$ and $77 \%$ (Eurobarometer, 2017, pp. 59-60). The fact that trade attitudes towards free trade remained steady during these various stages suggests that politicization has been more specific than general. Simultaneously, this also mirrors public opposition to TTIP being greater compared to any of the parallel EU trade negotiations.

Understood as 'an increase in the polarization of opinions, interests or values, and the extent to which they are publicly advanced towards the process of policy formulation within the EU' (de Wilde, 2011, p. 566), politicization did not play a decisive role in the majority of EU bilateral trade negotiations. Neither nontraditional societal actors nor the general public or the media paid significant attention to negotiations, thus playing mere spectator roles in (the ongoing, concluded or stalled) trade negotiations with developing countries such as China, India, Malaysia, Thailand and Vietnam or with developed countries such as Australia, Singapore, South Korea and Japan. (Inter-)regional negotiations such as those with the African, Caribbean and Pacific Economic Partnership Agreements (EPAs), the Andean Community, the Central American region and Mercosur did trigger some civil society resistance yet did not evolve into a large-scale European public mobilization. Due to the economic weight of the US and the EU, TTIP is the largest trade and investment agreement ever attempted and a prime example of what constitutes the next generation of a 'deep' trade agreement that led to 'an unprecedented public scrutiny' (Malmström, 2015, p. 2). Politicization's asymmetric dispersion hence illustrates that its occurrence was exceptional. This exceptionality resulted in TTIP being the outlier (Young, 2019).

While literature explaining the topical emergence of public mobilization during EU trade negotiations is abundant (De Bièvre \& Poletti, 2017; De Ville \&
Siles-Brügge, 2016; Eliasson \& Garcia-Duran Huet, 2019), it is presently complemented by scholars stimulating a research agenda in explaining the varying degrees of politicization across such trade negotiations (De Bièvre \& Poletti, 2020; Meunier \& Czesana, 2019). A consensus exists about various explanations of why the TTIP negotiations incited large public resistance. Accounting for the emergence of politicization are exactly those developments which instigated the abundant EU trade policy research mentioned above; institutional changes in the Lisbon Treaty, the content of trade and investment negotiations inducing stronger involvement of nontraditional societal actors, as well as the role and nature of the trading partner. Surprisingly, most efforts to explain the causes as well as the variation of trade politicization stubbornly focus on EU level institutions and actors (business associations, civil society organizations and trade unions). Despite scholars' acknowledgement of European governments' significance in shaping the common EU trade negotiation positions (Dür \& Zimmermann, 2007, p. 783; Laursen \& Roederer-Rynning, 2017, p. 765), the domestic level, 'where trade policy making actually begins and where member governments have to find negotiation positions that reflect their own domestic constraints' (van Loon, 2018a, p. 166), is-excepting a handful of studies (Adriaensen, 2016; Bauer, 2016; Bollen, 2018; Bouza \& Oleart, 2018; De Bièvre, 2018; Meunier \& Roederer-Rynning, 2020)-either mistakenly replaced by viewing the EU level as the domestic level, or plainly ignored. This lack of attention on the domestic level is astonishing as it is the level where trade policy making begins and where governments are constrained in finding negotiation positions originating from domestic societal demands. Assessing domestic level influences shaping governments' trade positions is thus a vital preceding component in comprehending how and why certain trade positions are pursued at the EU level. This deficiency, in looking at domestic factors to enrich knowledge, theoretical and empirical, has been criticized by van Loon (in press), who states that explanations for why European governments vary in trade positions and priorities, and how and by whom these are generated in the domestic preference formation process, remain largely unanswered. An accentuation on the origins of governments' trade positions offer a timely and relevant point of view and thus should be taken seriously in future research on EU trade policy (van Loon, 2018b, p. 107).

This study hence aims to illuminate the domestic level and-not by only opening but by explicitly unfolding the black box-its goal is to trace and explain variation of politicization across the TTIP trade positions of the United Kingdom (UK) and Germany. Both countries are traditional advocates of trade liberalization and were expected to be the main TTIP beneficiaries among the EU countries (Felbermayr, Heid, \& Lehwald, 2013, p. 43). Yet at the height of trade politicization this did not translate into similar TTIP positions. Whereas the British government was a constant enthusiastic TTIP promoter, 
the German government, originally a fervent supporter, gradually signaled a more reserved TTIP backing. It is shown that politicization shaped the UK's enthusiastic, and Germany's reserved, position on trade, correlating with differences in interests and ideas prevalent in these countries' domestic politics. The article proceeds in the following three steps. The next section, and while touching on several domestic politics approaches, presents the societal approach to governmental preference formation (Schirm, 2011, 2013, 2016, 2020). This includes defining the variables, formulating the core hypotheses and explaining the operationalization. This is followed by the empirical case study which examines whether the TTIP positions of the governments under scrutiny correspond to domestic material interests or societal ideas, and whether these are in line with national institutions in a cross-country comparison. The last section concludes with a brief comparative summary on the theoretical and empirical findings.

\section{The Societal Approach to Governmental Preference Formation}

The societal approach to governmental preference formation is employed to account for the selective politicization since its eminent accentuation on endogenous societal considerations, interests, ideas and institutions dominant in countries' domestic politics, prior to international or intergovernmental negotiations (Schirm, 2013, p. 690), allows for not only opening but an explicit unfolding of the black box in explaining variation in governments' positions. While employing and augmenting domestic politics theories such as IR liberalism (Moravcsik, 1997), domestic sources of economic policies (Goldstein \& Keohane, 1993; Keohane \& Milner, 1996), historical institutionalism (Fioretos, 2011) as well as varieties of capitalism (Hall \& Soskice, 2001), the societal approach, 'developed as a complementary approach' (Schirm, 2020, p. 5) engages in a unique advancement and refinement of these. Akin to these theories, its core assumption is that, in democratic political systems, elected governments intent to remain in office; ergo their positions mirror societal actors' preferences. Yet, contrary to hailing the importance of either domestic interests or ideas or institutions, this analytical instrument embraces all three domestic explanatory variables in explaining governmental preference formation as the dependent variable (Schirm, 2016, p. 68).

Goldstein and Keohane (1993, p. 25) and Milner (1997, p. 16) point to domestic factors' interrelationship, yet truly exploring this interdependence requires further theoretical development. Providing a systematic examination of the individual role of domestic interests, ideas and institutions, in supporting or opposing each other, as well as their interplay in shaping governments' positions is a crucial innovative aspect of the societal approach. It is essential in advancing existing domestic politics approaches, both theoretically and empirically, which makes its distinctiveness a novelty. Consequently, a theory-guided empirical investigation is incomplete by solely determining which of these explanatory variables accounts for variation across governments' positions. A further step is necessary to complete the picture, which involves analyzing why domestic interests dominate in shaping government's trade positions in some cases, whereas ideas and institutions prevail in other situations. Schirm (2020, p. 9) notes that this facet on the conditions under which each variable becomes more important and prevails in shaping governmental preferences' is hitherto not included in previous domestic politics approaches. By employing said variables this study addresses the alluring developments such as the expansion of the trade agenda triggering a more active engagement of non-traditional societal actors. With EU trade increasingly impinging countries' domestic politics, thereby mobilizing a range of materially and ideationally motivated societal stakeholders, who aim to shape their respective governments' trade positions, this approach is both timely and warranted.

Echoing previous scholars' research output, the societal approach attaches domestic actors and structures certain attributions. Building on and furthering Milner (1997) and Moravcsik (1997), the 'material interest' variable is defined as economic sectors' short-term distributional calculations which adjust promptly to alterations in the international economy (e.g., the desire for trade protection vs. the demand for trade liberalization). 'Societal ideas' are defined as voters' durable, valuebased, shared expectations of apt government behavior in steering the economy (e.g., trust in market forces vs. governmental regulation). The definition of 'national institutions' expands on Fioretos' (2011), as well Hall and Soskice's (2001) line of thought in identifying these as formal arrangements of socio-economic coordination (e.g., coordinated market economy [CME] vs. liberal market economy [LME]). In order to be able to account for a broader array of domestic stakeholders, and the respective governments' responsiveness to their demands, further domestic actors are added in the analysis; The materially motivated sectoral business associations are complemented by trade unions considered as sources for domestic interests, and ideationally motivated voters are complemented by NGOs as sources for societal ideas.

The variables' explicit specification supports the articulation of individual hypotheses proposing 'conditions under which each variable becomes more important' (Schirm, 2020, p. 9) in shaping the governments' trade positions. These central hypotheses, accounting for the impact of economic sectors (interests) and societal expectations (ideas), as well as domestic structures (institutions), are conceptualized, and inserted within the trade context, as follows: 1) When economic sectors face meaningful distributional calculations, material interests predominate in shaping the governments' TTIP positions due to intense lobbying, and 2) when fundamental questions on the role of politics in steering the 
economy are affected and economic sectors face diffuse distributional concerns, societal ideas will prevail in shaping the governments' TTIP positions. Accounting for the variables' interplay, the following hypothesis states that when both cost-benefit calculations for economic sectors as well as fundamental societal expectations on governments' apt role in steering the economy are affected, then these compete and weaken, or reinforce and strengthen each other in shaping governments' TTIP positions. Additionally, when the issue concerns questions on formal arrangements of socio-economic coordination, the governments' TTIP positions will be consistent with national institutions. The effect of material interests and societal ideas on governmental preference formation is strengthened when these institutional frameworks are present, while the absence of these national arrangements dilute the influence of domestic factors' in shaping governmental positions (Schirm, 2016, p. 69).

In terms of operationalization, this study analyses the rhetorical logic, the discourse between the domestic stakeholders and responsible elected politicians in the UK and Germany, during the TTIP negotiations, particularly regarding the issues of the investor-to-state dispute settlement (ISDS) mechanism and food safety standards, covering the period 2013-2016. The relevance of the three independent variables for the divergent governments' TTIP positions is examined by identifying indicators of the expectations of sectoral business associations, trade unions, voters and NGOs during the TTIP negotiations. Centre of attention are these actors' statements in press releases, position papers, public opinion polls, official websites and secondary sources with the objective to identify the substantive origins and concerns at the core of politicization. Material interests are demonstrated through statements and positions papers of business associations and trade unions in order to examine the directly affected domestic economic sectors and the incentives of sectoral lobbying vis-à-vis the respective governments. Societal ideas are illustrated by measuring public opinion polls revealing durable fundamental expectations of voters in the form of values, as well as by position papers and statements of NGOs, on the apt governmental behavior in steering the economy, which are viewed more legitimate and acceptable in some TTIP negotiations issues than in others. National institutions are delineated by considering long-term complementarities resulting from two diverse institutional frameworks shaped by the structure of national economies, the CME-LME dichotomy, as well as the different images of government-society relations, in the form of consensus-based vs. majoritarian competition-oriented decision-making, which shows whether material interests and societal ideas tend to be consistent with these, thus potentially having shaped the governments' positions in TTIP negotiation issues.

Based on the assumption of governments' aim to remain in office, thereby inducing responsivity, the dependent variable is supported mainly by governmental doc- uments and statements. Briefly put, evidence is sought for a correlation between the stated concerns of supporters and opponents, and the respective governments' responsiveness to these concerns in their preference formation process during the TTIP negotiations. The UK and Germany, under scrutiny due to their variation in TTIP trade stances, were chosen to compare different sets of interests, ideas and institutions-the UK representing a LME shaped by financial services and Germany serving as a CME shaped by manufacturing-and concerning the appropriate role of government-British adhering more to trusting market forces and Germans attaching more confidence to governmental regulation (World Values Survey, 2005-2009). This dyad of ideas relates to 'path-dependent ideas and their codified institutional form' concerning the two countries' political systems and their political process of decision making (Schirm, 2011, p. 58). In the case of the UK, this stresses a government which acts as a referee among competing societal groups and a more winner-takes-it-all 'majoritarian and competitive decision-making,' while in Germany, the government is perceived as an intermediator through an inclusion of all relevant societal groups in the form of 'consensual decision-making' (van Loon, in press). Adoption of a most different setting hence allows for the presumption that, in a cross-country comparison, different domestic interests, ideas and institutions have indeed shaped the two governments' trade positions.

\section{Unfolding the Black Box: Domestic Politics in the UK and Germany}

TTIP's prime objective was 'to increase trade and investment' in order to create 'jobs and growth through increased market access and greater regulatory compatibility and setting the path for global standards' through four suggested measures: (1) elimination of tariffs, (2) reducing discriminatory policy measures supporting domestic providers of goods and services, (3) increasing convergence and mutual recognition of regulatory standards thereby lowering costs of EU and US suppliers, and (4) including investment protection and ISDS (European Council, 2014, p. 4). This illustrates the move from concentrating primarily on reducing border barriers to the free movement of goods such as tariffs, from the 1990s onwards focus was primarily on reducing behind-theborder restrictions on goods and barriers to trade in services. While in 2013, EU Trade Commissioner De Gucht referred to TTIP as 'the cheapest stimulus package that can be imagined' (De Gucht, 2013), in 2015, Trade Commissioner Malmström made the case for TTIP as being a 'no-brainer' with increasing trade having 'two overriding priorities: jobs and growth' (Malmström \& Hill, 2015). Following these two goals and the alleged prosperity it was supposed to bring, TTIP was thereby in particular corresponding to the results of European respondents' opinion-more than six in ten citizens from 21 of the $27 \mathrm{EU}$ member states believed that interna- 
tional trade should be a vector of domestic job creation (Eurobarometer, 2010, p. 70). Although the majority of $24 \mathrm{EU}$ member governments were in favor of TTIP (Eurobarometer, 2016, p. 19) the [TTIP] discussion was 'a few degrees hotter in Germany than in other countries' (Tost, 2015). Increased opposition to a EU FTA with the US was particularly high in Germany-from 41\% in 2014 to $52 \%$ in 2016 -compared to a rather consistent low percentage of opposition from UK respondents-19\% in both 2014 and 2016 (Eurobarometer, 2014, p. 202; 2016, p. 19).

In the following, the argument that both countries' TTIP positions were shaped by material interests, societal ideas and national institutions will first of all be examined by providing empirical data from British and German business associations and trade unions which is then followed by presenting public opinion data and statements from NGOs. This data illustrates whether the governments' TTIP positions reflected the domestic factors dominant in these countries. The analysis will then simultaneously highlight under which conditions the variables shaped the governments' trade positions.

\subsection{Material Interests in the UK and Germany}

Leading umbrella business associations in both the UK and Germany were in favor of TTIP, whereas both countries' trade unions were rather skeptical. The Confederation of British Industry's report A New Era for Transatlantic Trade stated potential TTIP gains for small and medium-sized businesses from the harmonization of regulatory standards, market access and export opportunities for UK services, a rise of UK jobs due to an increase in investment, as well as a larger range of products at cheaper prices for consumers (CBI, 2014, p. 2). With the US being the UK's largest market outside the Eurozone, the CBI believed that TTIP 'was something worth pursuing in the current economic climate' (House of Commons, 2015, p. 6). CBI Brussels Director, Sean McGuire, referred to EU countries being party to investment treaties with ISDS provision and stated the necessity to 'uphold basic rules on investor protection [as] the right of states to regulate in the public interest, would help set a precedent for EU investment negotiations with other strategic trading partners like China' (Policy Review, 2015). The British Chamber of Commerce equally supported free trade between the EU and the US, particularly for small and medium-sized companies. Director General, John Longworth, stressed that 'firms across the UK will cheer a free trade deal that helps them gain new opportunities in US markets' (Longworth, 2015). The Trade Union Congress (TUC) acknowledged the potential economic benefits of TTIP, and noted that the reduction of tariffs and economic regulations, 'could genuinely lead to greater trade and greater benefits to all' in specific sectors such as the automobile and chemical industries (House of Commons, 2015, p. 6). It was however uncertain about potential job creation and viewed that the threats to public services, workers' rights as well as environmental and food standards would outweigh any potential benefits. The TUC believed that TTIP's primary purpose was to privilege foreign investors by providing transnational corporations with more power and influence, enabling them to sue states whose laws or actions are deemed incompatible with free trade. TUC's Sally Hunt, expressed its opposition 'to ISDS in TTIP and indeed any trade deal as it is undemocratic and against the public interest to allow foreign investors to use special secretive courts to sue governments for making public policy they think is bad for business' (TUC, 2014).

In a survey from the Association of German Chambers of Industry and Commerce (DIHK), TTIP was welcomed by an overwhelming majority from German industry $-70 \%$ of the German 'Mittelstand' regarded TTIP as positive. Featuring the most important issue of $85 \%$ of respondents in facilitating bilateral trade was the adaptation or mutual recognition of equivalent norms, standards and certifications, followed by simpler customs clearance which was important for $83 \%$ of respondents. This number was even higher in the retail and agri-food industry branches ( $91 \%$ and $90 \%$, respectively). Tariff elimination was viewed by $75 \%$ of respondents as important, especially for the retail and the agri-food sectors (both $82 \%$ ), as well as for the automobile industry and suppliers (81\%). The DIHK and other leading business associations, the Federation of German Industries, the Confederation of German Employers' Associations, and the German Confederation of Skilled Crafts issued a joint statement calling for an ambitious and fair trade and investment agreement and to 'make use of this opportunity' (Federation of German Industries, 2014, p. 1) in removing barriers in the transatlantic market, thereby 'achieving more growth, more employment, new market opportunities and therefore future prospects for companies and employees' (Federation of German Industries \& Confederation of German Employers' Associations, 2014, p. 2). Leading the pro-TTIP campaign, the Federation of German Industries viewed the ISDS compatible with governments' ability to regulate, as well as an opportunity to reform the international investment system and to introduction higher standards for future trade agreements (Mildner, 2014). In its first position paper of 2013, the Confederation of German Trade Unions (DGB) criticized the US' non-ratification of six out of eight basic core labor standards of the International Labor Organization and called for a suspension of the TTIP trade negotiations. It demanded that 'one of the objectives of the agreement with the US must be an improvement of labor rights everywhere' (DGB, 2013, p. 4). In its position paper one year later, it stated its main concerns, the different levels of protection for consumers, the environment as well as the workforce, and called for TTIP 'to provide greater prosperity for a broader segment of the population, improve economic, social and environmental standards, and create structures for fair competition and good working conditions' (DGB, 2014, p. 4). 


\subsection{Societal Ideas in the UK and Germany}

At TTIP's launch in 2013, both UK (58\%) and German (56\%) attitudes among the general public were positive towards increased trade and investment between the EU and the US. Attitudes were equally similar towards free trade in general, with $77 \%$ of UK respondents and $74 \%$ of German respondents being supportive (Eurobarometer, 2014). When asked about specific TTIP support, 39\% of German respondents were in favor and $41 \%$ respondents were against TTIP, while $65 \%$ of respondents were in favor and 19\% were against TTIP in the UK (Eurobarometer, 2014). German TTIP attitudes declined in 2015 with 31\% in favor and $51 \%$ of respondents against the agreement. The numbers stayed relatively stable in the UK with $63 \%$ in favor of TTIP and $20 \%$ of respondents against (Eurobarometer, 2015). Van Loon (2018a, p. 172) points to these varying German public attitudes towards increased economic relations with the US, free trade in general and TTIP attitudes in specific. German attitudes towards TTIP were thus not related to free trade in general; instead 'the potential partner and the agreements' content unrelated to trade' is what mattered (Jungherr, Mader, Schoen, \& Wuttke, 2018, p. 216). Reflecting the four measures to achieve TTIP's objectives, tariffs, regulations, rules and investment, the issues of perceived governments' limitation in regulating the domestic market potentially leading to a decline in consumer protection and supposed loss of democratic accountability due to the agreement's ISDS introduction, were prominent in the German public discourse. As opposed to traditional tariff cutting trade issues, public TTIP attitudes were less focused on the potential threat of increased international competition, but rather on its impact on national or European standards and policy processes as the agreement could be misused by companies as a back door, circumventing and undermining consumer protection rights as well as environmental standards: $51 \%$ of respondents opposed the harmonization of US and EU standards for products and services, $53 \%$ was against the removal of restrictions on investment between the EU and the US, while a vast majority of Germans showed fundamentally high trust levels in European standards on issues such as food safety (94\%), auto safety (91\%) and environmental safety (96\%) (Pew Research Center \& Bertelsmann Foundation, 2014, pp. 22-23).

Regarding food safety concerns, $56 \%$ of Germans believed that chlorinated chicken poses a health risk (Stern, 2014). This highlights the connection between Germans' beliefs in consumer protection and their strong preferences for governmental regulation; German respondents attach a greater significance to the role of government in steering the economy, whereas the British counterparts are more supportive of responsibility of market forces, reflecting both countries' capitalism types as a LME and CME (Schirm, 2011, p. 51). Against this background, a crucial factor in German TTIP attitudes was their skeptical view of transatlantic relations inciting a general distrust in German-American relations (Braml, 2014). In 2014, $73 \%$ of respondents thought that the US buying German companies would be negative for the German economy (Pew Research Center \& Bertelsmann Foundation, 2014, p. 23) while almost the majority (49\%) believed that it would hurt the economy if the US would build new factories in Germany (Pew Research Center \& Bertelsmann Foundation, 2014, p. 22). This correlates with results from the Pew Research Center which reveals that America's international image has become more negative among German respondents since 2011, falling from $62 \%$ having a favorable opinion in 2011 to $50 \%$ in 2015 , vs. $61 \%$ of UK respondents viewing the US positively in 2011 against a slight increase, reaching $65 \%$ assigning a positive rating, in 2015 (Pew Research Center, 2015, p. 13).

Much backlash against TTIP came from civil society groups, and UK and German NGOs' criticism particularly focused on the ISDS and TTIP's potential risks on environmental, consumer, health and labor rights. The German NGO sector, an alliance of around 70 members, created an online platform 'TTIP unfairhandelbar' (www.ttipunfairhandelbar.de) and provided critical views thereby informing members about discussion events and demonstrations. The British NGO sector created a similar counterpart 'NoTTIP' (https:// www.nottip.org.uk) with around 50 members. Rejecting ISDS, the German NGO alliance demanded 'legal protection for people-instead of privileged right of action for corporations' dismissing giving international companies 'their own special rights to take action against governments' (Forum on Environment and Development, 2014 , p. 2). With the ISDS favoring investors, and not citizens, as well as facilitating the protection of foreign, and not national, investors' rights, this was severely criticized. German and UK NGOs stated that the ISDS 'threatens to undermine the most basic principles of democracy' (Hilary, 2015, p. 30). Regarding the position on food safety standards, NGOs in both countries feared that the agreement would result in a so-called race to the bottom on European food safety standards. The 'TTIP unfairhandelbar' NGO alliance stated that the non-negotiability of the alleged stricter European standards should not be diminished 'nor undermined by a mutual recognition of American and European standards' (Forum on Environment and Development, 2014, p. 2). In the UK, a War on Want position paper (member of the 'NoTTIP' alliance) voiced its concern of TTIP's potential impact on public services, in specific the 'further market opening' or the potential 'to lock-in past privatizations of the NHS' and demanded 'a full and un-equivocal exclusion of all public services from any EU trade agreements and the ongoing trade negotiations' (War on Want, 2015, p. 46).

\subsection{Domestic Factors Shaping Governments' TTIP Positions}

UK Prime Minister David Cameron, strongly in favor of TTIP said, 'there is no more powerful way to achieve 
[economic growth] than by boosting trade' (Cameron, 2013). The UK government acknowledged TTIP's large benefits 'adding as much as $\mathrm{f10}$ billion annually to the UK economy in the long-term' as well as increasing jobs and lower prices for goods and services (UK Government, 2014 , p. 5). Softening concerns about inclusion of the NHS and challenges of potential ISDS provisions were issued by Lord Livingston of Parkhead, then Business, Innovations and Skills' (BIS) Minister of State emphasizing that 'TTIP will not change the fact that it is up to the UK to decide how public services, including the NHS, are run' (BIS, 2014). This was supported by Cameron who deemed these concerns 'nonsense' as 'there is no threat, I believe, from TTIP to the National Health Service and we should just knock that on the head as an empty threat' (Cameron, 2014). The government, having signed numerous trade agreements including investment protection provisions, and thus in favor of the ISDS, had brought arguments to the fore that this mechanism would need to find the right balance between investment protection and the rights of the national government to regulate. BIS Secretary of State, Vince Cable said that 'neither the investment protection provisions nor decisions arising from ISDS cases will affect the ability of the UK government to regulate fairly and in the public interest' (Cable, 2014). This thus illustrates that although there was a certain ambivalence between material interests as well as among societal ideas, the government did not include all competing domestic groups, as its stance was shaped more by those material interests and societal ideas that favored TTIP.

In Germany, the Christian Democratic (CDU)/Social Democratic (SPD)-led government clearly stated the commitment towards a speedy conclusion of TTIP (Christian Democratic Union, 2013, p. 13). It however adopted a skeptical stance in 2014 regarding the ISDS issue. Opposition came especially from the governing SPD, calling for the exclusion of the mechanism in TTIP. In March 2014, the SPD party leader, Vice Chancellor and Economics Minister, Sigmar Gabriel emphasized the governments' position in a letter to then EU Trade Commissioner De Gucht. Gabriel wrote that the US and Germany already offered adequate legal protections to investors, so that ISDS provisions would not be required in a transatlantic agreement (Handelsblatt, 2014). Since then, the SPD had somewhat rowed back concerning its ISDS position. During the CETA negotiations, Gabriel backed down by stating that if the rest of Europe wants this agreement, then Germany must also approve' (Sarmadi, 2014). Chancellor Angela Merkel (2015a), calling for a TTIP 'which has many winners' stated that the many investment protection agreements Germany previously negotiated had not been under public scrutiny and that TTIP would induce 'a new international standard for investment protection.' She diluted concerns saying that such provisions 'were of great importance to many companies in Germany because they were protected from arbitrary situations in certain countries to which they would otherwise have been exposed' (Merkel, 2015a). Businesses, service providers and consumers would garner benefits from TTIP, leading to reduced prices, a larger range of products, a rise in sales resulting in generating an increase in jobs, yet 'our standards, for instance on consumer protection, environmental protection and health protection are non-negotiable' (Merkel, 2015b). The government and the DGB issued a joint position paper in which they stressed TTIP opportunities in intensifying trade relations making trade fair and sustainable, yet both emphasized that trade issues such as workers' rights, consumer protection, social and environmental standards were not to be jeopardized (BMWi, 2014, p. 1). This joint paper illustrates the German government's responsiveness to material interests in favor of TTIP, but also to interests opposed to TTIP. However, its position corresponded equally well to the concerns of societal ideas, and thus its reserved TTIP stance was shaped by the ambivalence of both types of domestic factors, interests and ideas, which was the result of its inclusion of all domestic groups.

\section{Conclusion}

The goal of this article was to trace and explain selective politicization across the TTIP trade positions of the UK and Germany. It has illustrated that a trade agreement's content can fuel politicization when a broad range of materially motivated and ideationally motivated stakeholders are affected by this. In line with the societal approach to governmental preference formation, the TTIP positions of the UK and Germany were strongly shaped by material interests, societal ideas and national institutions. These domestic variables' significance has been theoretically stressed and empirically examined, thereby accounting for the predominance of material interests when the issue at stake concerns distributional consequences for economic sectors, while societal ideas dominate when fundamental concerns of the role of government in steering the economy are at stake. When both are affected, they can either compete and weaken each other, or reinforce and strengthen each other, while the governments' positions are consistent with national institutions when the issue concerns questions of formal arrangements of socio-economic coordination.

The UK government's position was shaped by the preferences of business associations' who were directly affected by TTIP's distributional impact. Although UK business interests favored TTIP, and the TUC represented a skeptical TTIP stance, material interests nevertheless shaped an enthusiastic and strong government position. This variables' ambivalence means that the trade union's concerns did not weaken business interests' preferences in shaping the UK government's position. Thus, a position corresponding more to those material interests in favor of TTIP also correlates with LME institutions and societal ideas of trust in market forces. In addition, concerning the trade issues, especially regulation and safety 
standards, the government showed a weak responsiveness to the concerns of NGOs. The ambiguous relationship between NGOs opposed to TTIP and voters in favor of TTIP, illustrates that the former did not weaken the latter. In sum, business associations and voters were predominant in shaping the UK's TTIP position.

Equal to the UK government's stance, its German counterpart corresponded to material interests, directly affected by TTIP's potential distributional consequences. Again, these concerns were not identical, as business associations were strongly supportive, yet trade unions were against TTIP, thus weakening each other. The government included these ambivalent material interests in its trade policy position. On issues such as the role of government in steering the economy, ISDS, and food safety standards, the German TTIP stance correlated with the institutions of the CME and corresponded to societal ideas of trust in governmental regulation, with the voters' and NGOs' concerns reinforcing each other. Overall it should be noted, that with the trade union (DGB), NGOs, and voters all opposed to TTIP, the reserved German TTIP position was shaped by both domestic factors, interests and ideas, and thus in line with national institutions.

The aim of this article was to provide an explanation of the differences in politicization in the UK and Germany during the TTIP negotiations, thereby illuminating the domestic level of EU trade policy making by unfolding the black box and specifying a comprehensive understanding of the countries' domestic politics. The employed societal approach to governmental preference formation and its distinctiveness in complementing domestic politics approaches emphasizes the explicit specification of the domestic variables, interests, ideas and institutions. This supports the conceptualization of the hypotheses empirically examining the conditions for the prevalence of these vis-à-vis each other. Since the bulk of the literature on EU trade policy has long marginalized the domestic level, this study has shown the explanatory power of the societal approach in embracing all three domestic factors and explaining their origins, as well as their interdependence, in shaping the varying TTIP positions of the UK and German governments. As EU trade policy will remain in full spotlight for years to come, this contribution has thus made the case for a future accentuation on domestic factors for understanding the selective trade politicization across EU member states.

\section{Acknowledgments}

The author would like to thank the Academic Editors, the participants of the 5th EISA EWIS workshop on 'The Politics of Foreign Policy Change: Domestic Political Actors as Agents of Change' (June 2018) at the University of Groningen, as well as the participants of the Workshop on 'Trade Politicization' at IBEI Barcelona (July 2018) and two anonymous reviewers for helpful comments on the article's draft version. Sincere gratitude goes to André van Loon for valuable assistance and detailed feed- back. Open access funding is provided by the University of Antwerp.

\section{Conflict of Interests}

The author declares no conflict of interests.

\section{References}

Adriaensen, J. (2016). National administrations in EU trade policy: Maintaining the capacity to control. London: Palgrave Macmillan.

Bauer, M. (2016). The political power of evoking fear: The shining example of Germany's anti-TTIP campaign movement. European View, 15(2), 193-212.

BMWi. (2014). Transatlantic Trade and Investment Partnership (TTIP): Anforderungen an Freihandelsgespräche zwischen der EU und den USA unter der Berücksichtigung von Nachhaltigkeit, Arbeitnehmerrechten und der Gewährleistung der Daseinsvorsorge. [Requirements for EU-US free trade negotiations, taking into account sustainability, labour rights and the guarantee of services of general interest]. BMWi. Retrieved from https://www.bmwi.de/ Redaktion/DE/Downloads/S-T/ttip-dgb-bmwi.pdf? blob=publicationFile\& $\mathrm{v}=1$

Bollen, Y. (2018). The domestic politics of EU trade policy: The political-economy of CETA and anti-dumping in Belgium and the Netherlands (PhD thesis). University of Ghent, Ghent, Belgium.

Bouza, L., \& Oleart, A. (2018). From the 2005 constitution's 'permissive consensus' to TTIP's 'empowering dissensus': The EU as a playing field for Spanish civil society. Journal of Contemporary European Research, 14(2), 87-104.

Braml, J. (2014, July 11). Germany's sense of betrayal takes it away from US patron. Financial Times. Retrieved from https://www.ft.com/content/ 77dd099e-090f-11e4-906e-00144feab7de

Business, Innovations and Skills. (2014). Letter from Lord Livingston of Parkhead. Transatlantic Trade and Investment Partnership (TTIP) on the National Health Service. War on Want. Retrieved from https:// waronwant.org/sites/default/files/Lord\%20 Livingston\%20to\%20MPs\%20-\%20TTIP\%20-\%20 December\%202014.pdf

Cable, V. (2014, November 12). TTIP: Vince Cable's response to 'TTIP: No public benefits, but major Costs.' GOV.UK. Retrieved from https://www.gov.uk/ government/publications/ttip-vince-cablesresponse-to-ttip-no-public-benefits-but-major-costs

Cameron, D. (2013). Speech G8 Summit: US \& EU Trade Statement. GOV.UK. Retrieved from https:// www.gov.uk/government/speeches/g8-summit-useu-trade-statement

Cameron, D. (2014). David Cameron press conference G20, Brisbane, Australia. GOV.UK. Retrieved from https://www.gov.uk/government/speeches/david- 
cameron-press-conference-g20-brisbane-australia

Christian Democratic Union. (2013). Deutschlands Zukunft Gestalten. Koalitionsvertrag zwischen CDU, CSU und SPD: 18. Legislaturperiode [Shaping Germany's future. Coalition agreement between the CDU, CSU and SPD: 18th legislative period]. Rheinbach: Union-Betriebs $\mathrm{GmbH}$ Rheinbach.

Confederation of British Industry. (2014). A new era for transatlantic trade: Five top reasons to support TTIP. CBI.

Confederation of German Trade Unions. (2013). Statement of the German Trade Union Confederation (DGB) concerning the planned negotiations for a Transatlantic Trade and Investment Partnership between the EU and the US (TTIP), April 29 2013. Confederation of German Trade Unions.

Confederation of German Trade Unions. (2014). DGB position: Suspend the negotiations for a Free Trade Agreement with the USA-No Agreement at the expense of workers, consumers or the environment. $D G B$. Retrieved from https://www.dgb.de/themen/ ++co++39c1026e-0d92-11e4-906b-52540023ef1a

De Bièvre, D. (2018). The paradox of weakness in European trade policy: Contestation and resilience in EU, CETA and TTIP negotiations. The International Spectator, Italian Journal of International Affairs, 53(3), 70-85.

De Bièvre, D., \& Poletti, A. (2017). Why the Transatlantic Trade and Investment Partnership is not (so) new, and why it is not (so) bad. Journal of European Public Policy, 24(10), 1506-1521.

De Bièvre, D., \& Poletti, A. (2020). Towards explaining varying degrees of politicization of EU trade agreement negotiations. Politics and Governance, 8(1), 243-253.

De Gucht, K. (2013, February 21). Transatlantic Trade and Investment Partnership: Opening free trade negotiations with the United States. European Commission. Retrieved from https://ec.europa.eu/commission/ presscorner/detail/en/SPEECH_13_147

De Ville, F., \& Siles-Brügge, G. (2016). TTIP: The truth about the transatlantic trade and investment partnership. Cambridge: Polity Press.

de Wilde, P. (2011). No polity for old politics? A framework for analysing the politicization of European integration. Journal of European Integration, 33(5), 559-575.

Dür, A., \& Zimmermann, H. (2007). Introduction: The EU in international trade negotiations. Journal of Common Market Studies, 45(4), 771-787.

Eliasson, L. J., \& Garcia-Duran Huet, P. (2019). Civil society, rhetoric of resistance, and transatlantic trade. Cham: Palgrave Macmillan.

Eurobarometer. (2010). International trade report (Special Eurobarometer 357). Brussels: European Commission.

Eurobarometer. (2014). Standard Eurobarometer 82 (Autumn 2014 Report). Brussels: European Commission.
Eurobarometer. (2015). Standard Eurobarometer 83 (Spring 2015 Report). Brussels: European Commission.

Eurobarometer. (2016). Standard Eurobarometer 86 (Autumn 2016 Report). Brussels: European Commission.

Eurobarometer. (2017). Designing Europe's future: Trust in institutions, globalisation, support for the Euro, opinions about free trade and solidarity (Special Eurobarometer 461). Brussels: European Commission.

European Commission. (2017). A balanced and progressive trade policy to harness globalization (COM [2017] 492 final). Brussels: European Commission. Retrieved from https://ec.europa.eu/info/ balanced-and-progressive-trade-policy-harnessglobalisation_en

European Council. (2014, October 9). Directives for the negotiation on the Transatlantic Trade and Investment Partnership between the European Union and the United States of America. Brussels: European Council.

Federation of German Industries, \& Confederation of German Employers' Associations. (2014). Brussels update: December. BDI. Retrieved from https://www.arbeitgeber.de/www/arbeitgeber.nsf/ res/5D14B6E79E61E945C1257DAC002EAE20/\$file/ Bruessel-Aktuell-Dez-2014.pdf

Federation of German Industries. (2014). Joint Statement by BDA, BDI, DIHK, and ZDH on TTIP: An opportunity for employment and the economy. Berlin: BDA. Retrieved from https://www.arbeitgeber.de/www/ arbeitgeber.nsf/res/An\%200pportunity\%20for\% 20Employment\%20and\%20the\%20Economy.pdf/ \$file/An\%200pportunity\%20for\%20Employment\% 20and\%20the\%20Economy.pdf

Felbermayr, G., Heid, B., \& Lehwald, S. (2013). Transatlantic trade and investment partnership: Who benefits from a trade deal? Gütersloh: Bertelsmann Foundation.

Fioretos, O. (2011). Historical institutionalism in international relations. International Organization, 65(2), 367-399.

Forum on Environment and Development. (2014). "TTIP": No thanks! There are other ways to create a transatlantic partnership. Berlin: German NGO Forum on Environment and Development. Retrieved from http://www.ttip-unfairhandelbar.de/fileadmin/ download/material/engl_pospap_ttip_web_ 24April2014.pdf

Goldstein, J., \& Keohane, R. O. (Eds.). (1993). Ideas and foreign policy: Beliefs, institutions and political change. Ithaca, NY: Cornell University Press.

Hall, P. A., \& Soskice, D. (Eds.). (2001). Varieties of capitalism. The institutional foundations of comparative advantages. Oxford: Oxford University Press.

Handelsblatt. (2014, March 27). Politiker streiten um Investitionsschutz [Politicians argue about investment protection]. Handelsblatt. Retrieved from https://www.handelsblatt.com/politik/international/ freihandelsabkommen-politiker-streiten- 
ueberinvestitionsschutz/9679366.html?ticket=ST32189681-X43bOtdrxrg1ldbrPTHe-ap3

Hilary, J. (2015). The transatlantic trade and investment partnership agreement: A charter for deregulation and attack on jobs, an end to democracy. Brussels and London: Rosa Luxemburg Stiftung and War on Want.

House of Commons. (2015, March 17). Business, Innovation and Skills Committee, Transatlantic Trade and Investment Partnership (11th Report of Session 2014-15). London: The Stationary Office Limited.

Jungherr, A., Mader, M., Schoen, H., \& Wuttke, A. (2018). Context-driven attitude formation: The difference between supporting free trade in the abstract and supporting specific trade agreements. Review of International Political Economy, 25(2), 215-242.

Keohane, R. O., \& Milner, H. V. (Eds.). (1996). Internationalization and domestic politics. Cambridge: Cambridge University Press.

Laursen, F., \& Roederer-Rynning, C. (2017). Introduction: The new EU FTAs as contentious market regulation. Journal of European Integration, 39(7), 763-779.

Longworth, J. (2015). BCC comments on the BIS select committee's report on TTIP [Press release]. London: British Chambers of Commerce. Retrieved from https://www.britishchambers.org.uk/news/ category/international-trade

Malmström, C. (2015, July 7). Opening remarks at EP debate on TTIP. Brussels: European Commission. Retrieved from http://trade.ec.europa.eu/doclib/docs/ 2015/july/tradoc_153598.pdf

Malmström, C., \& Hill, J. (2015, February 16). Don't believe the anti-TTIP hype: Increasing trade is a no-brainer. The Guardian. Retrieved from https:// www.theguardian.com/commentisfree/2015/feb/ 16/ttip-transatlantic-trade-deal-businesses

Merkel, A. (2015a). Rede von Bundeskanzlerin Merkel auf dem Kongress "Ja zu TTIP! Chancen nutzen, Interessen wahren, Zukunft gestalten" [Speech by Chancellor Merkel at the congress "Yes to TTIP! Use opportunities, protect interests, shape the future"]. Die Bundesregierung. Retrieved from https:// www.bundesregierung.de/breg-de/suche/redevonbundeskanzlerin-merkel-auf-dem-kongress-jazu-ttip-chancen-nutzen-interessen-wahren-zukunftgestalten-der-cducsu-fraktion-am-21-september2015-428812

Merkel, A. (2015b). Angela Merkel for the free trade agreement: "TTIP is a fantastic opportunity." The Federal Government. Retrieved from https://www. bundesregierung.de/breg-en/news/-ttip-is-afantastic-opportunity-430262

Meunier, S., \& Czesana, R. (2019). From back rooms to the street? A research agenda for explaining variation in the public salience of trade policy-making in Europe. Journal of European Public Policy, 26(12), 1847-1865.

Meunier, S., \& Roederer-Rynning, C. (2020). Missing in action? France and the politicization of trade and in- vestment agreements. Politics and Governance, 8(1), 312-324.

Mildner, S.-A. (2014). BDI submission: Consultation of the European Commission on investment protection and ISDS in TTIP. Berlin: BDI. Retrieved from https://bdi.eu/media/themenfelder/ aussenwirtschaftspolitik/TTIP/positionen/BDI_ ISDS_Consultation_final.pdf

Milner, H. V. (1997). Interests, institutions, and information: Domestic politics and international relations. Princeton, NJ: Princeton University Press.

Moravcsik, A. (1997). Taking preferences seriously: A liberal theory of international politics. International Organization, 51(4), 513-553.

Pew Research Center. (2015, June 23). Global publics back U.S. in fighting ISIS, but are critical of post9/11 torture. Pew Research Center. Retrieved from https://www.pewresearch.org/global/2015/06/23/ global-publics-back-u-s-on-fighting-isis-but-arecritical-of-post-911-torture

Pew Research Center, \& Bertelsmann Foundation. (2014). Support in principle for U.S.-EU trade pact: But some Americans and Germans wary of TTIP details. Washington, DC: Pew Research Center.

Policy Review. (2015). CBI: Why the UK needs TTIP by Sean McGuire, CBI Brussels Director. CBI. Retrieved from http://www.policyreview.co.uk/cbi-why-theuk-needs-ttip

Sarmadi, D. (2014, November 28). Sigmar Gabriel: 'Germany will approve CETA.' Euractiv. Retrieved from https://www.euractiv.com/section/trade-society/ news/sigmar-gabriel-germany-will-approve-ceta

Schirm, S. A. (2011). Varieties of strategies: Societal influences on British and German responses to the global economic crisis. Journal of Contemporary European Studies, 19(1), 47-62.

Schirm, S. A. (2013). Global politics are domestic politics: A societal approach to divergence in the G20. Review of International Studies, 39(3), 685-706.

Schirm, S. A. (2016). Domestic ideas, institutions or interests? Explaining governmental preferences towards global economic governance. International Political Science Review, 37(1), 66-80.

Schirm, S. A. (2020). Refining domestic politics theories of IPE: A societal approach to governmental preferences. Politics, 1-17. https://doi.org/ 10.1177\%2F0263395719896980

Stern. (2014). Deutsche haben keinen Appetit auf Chlorhünchen [Germans have no appetite for chlorine chickens]. Stern. Retrieved from https:// www.stern.de/wirtschaft/news/stern-umfragezum-freihandelsabkommen-deutsche-habenkeinenappetit-aufchlorhuehnchen-3941484.html

Tost, D. (2015, February 24). Malmström: Germany's TTIP debate 'more heated.' Euractiv. Retrieved from https://www.euractiv.com/section/trade-society/ news/malmstrom-germany-s-ttip-debate-moreheated 
Trade Union Congress. (2014). TTIP threats and opportunities: Speech by Sally Hunt at the ITUC world congress, Berlin. Retrieved from https://www.tuc. org.uk/speeches/ttip-threats-and-opportunities

UK Government. (2014). Government response to the House of Lords, European Union committee's fourteenth report: The transatlantic trade and investment partnership. London: Stationary Office.

van Loon, A. (2018a). Diverging British and German governmental trade policy positions in the Transatlantic Trade and Investment Partnership (TTIP) negotiations. Journal of Contemporary European Studies, 26(2), 165-179.

van Loon, A. (2018b). The political economy of EU trade policy: What do we (not) know? Zeitschrift für Politikwissenschaft, 28, 97-110.

van Loon, A. (in press). Domestic politics in European trade policy: Ideas, interests and variation in govern- mental trade positions. Abingdon: Routledge.

War on Want. (2015). Public services under attack: TTIP, CETA, and the secretive collusion between business lobbyists and trade negotiators. London: War on Want. https://media.waronwant.org/sites/default/ files/Public\%20Services\%20Under\%20Attack\%2C\% 202015_0.pdf?_ga=1.21 7551454.919079292. 1491476817

World Values Survey. (2005-2009). World Values Survey wave 5 2005-2009 (Selected samples Germany 2006, United Kingdom 2006). World Values Survey. Retrieved from http://www.worldvaluessurvey.org/ WVSOnline.jsp

Young, A. (2019). Two wrongs make a right? The politicization of trade policy and European trade strategy. Journal of European Public Policy, 26(12), 1883-1899.

\section{About the Author}

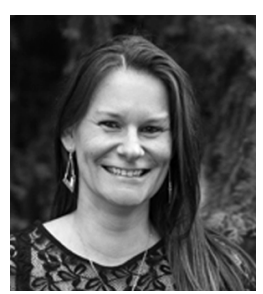

Aukje van Loon is Postdoctoral Research Associate and Lecturer at the Chair of International Politics, Ruhr University of Bochum, Germany. She is Co-Editor of the two-volumed Global Power Europe books (Springer) and author of the forthcoming book Domestic Politics in European Trade Policy: Ideas, Interests and Variation in Governmental Trade Positions (Routledge/UACES). Her research focuses on EU trade policy and post-crisis European economic governance which appears amongst others in The European Union and the BRICS (Springer), Journal of Contemporary European Studies and European Politics and Society. 